\title{
Evaluasi Karakteristik Hortikultura Empat Genotipe Melon (Cucumis melo L.) Pusat Kajian Hortikultura Tropika IPB
}

\author{
Evaluation of Horticultural Characteristics of Four Melon Genotypes (Cucumis $\underline{\text { melo }}$ L.) \\ from Centre Tropical Horticulture Study IPB
}

\author{
Wida W. Khumaero ${ }^{1}$, Darda Efendi ${ }^{1.2^{*}}$, Willy B. Suwarno ${ }^{1.2}$, dan Sobir ${ }^{1.2}$
}

Diterima 21 Januari 2014/Disetujui 12 Maret 2014

\begin{abstract}
Center for Tropical Horticulture Studies (CTHS) have conducted melon breeding to meet the need of the expanding melon production in Indonesia. Four melon genotypes of IPB Meta 3, IPB Meta 4, IPB Meta 6, IPB Meta 8 H exhibit superior performance during selection. Prior to release or to register, these melon genotypes need to be evaluated for their main characteristics. Four potential genotypes along with two control varieties of Action 434 and Sky Sweet were evaluated under a single factor Randomized Complete Block Design (RCBD) with four replications. The results revelaed that CTHS melon genotypes exhibited good performance. IPB Meta 4 has larger stem diameter and leaf size compared to Action 434 and Sky Sweet, subsequently flesh color of IPB Meta 3, IPB Meta 6, and IPB Meta $8 H$ are oranges, where as both control varieties are green. These results indicated that melon genotypes developed in CTHS have unique characteristics, which could be developed for speciality market.
\end{abstract}

Keywords: fruit quality, melon, morphological characteristics

\begin{abstract}
ABSTRAK
Pusat Kajian Hortikultura Tropika (PKHT) telah melakukan penelitian pemuliaan tanaman untuk mengetahui kebutuhan pengembangan produksi melon di Indonesia. Empat genotipe melon yakni IPB Meta 3, IPB Meta 4, IPB Meta 6, IPB Meta 8H menunjukkan penampilan baik pada percobaan sebelumnya. Sebelum dilepas atau didaftarkan, diperlukan evaluasi karakteristik utama dari empat genotipe tersebut. Pengujian keempat genotipe potensial dengan dua varietas pembanding yakni Action 434 dan Sky Sweet disusun berdasarkan Rancangan Kelompok Lengkap Teracak (RKLT) dengan 4 ulangan. Hasilnya menunjukkan bahwa genotipe melon IPB Meta 4 memiliki diameter batang dan ukuran daun yang lebih besar dibandingkan Action 434 dan Sky Sweet. Selain itu, daging buah melon genotipe IPB Meta 3, IPB Meta 6, dan IPB Meta 8H berwarna jingga, dimana kedua varietas pembanding berwarna hijau. Hasil ini menunjukkan bahwa genotipe-genotipe melon yang dikembangkan di PKHT memiliki karakteristik yang unik, dimana dapat berpotensi bagi segmen pasar khusus.
\end{abstract}

Kata kunci: karakteristik morfologi, kualitas buah, melon

\section{PENDAHULUAN}

Melon (Cucumis melo L.) merupakan salah satu komoditas buah-buahan yang banyak digemari oleh masyarakat karena melon memiliki berbagai keunggulan berupa rasa yang manis dan warna daging buah yang bervariasi. Selain itu melon memiliki nilai ekonomi dan prospek yang menjanjikan dalam aspek pemasaran (Sudiyarto, 2011).

Agribisnis melon memiliki peluang besar karena harganya yang cukup tinggi (Prajnanta, 2004). Melon dikenal juga sebagai buah yang menyehatkan karena mengandung berbagai vitamin dan mineral yang diperlukan tubuh manusia. Kandungan kalori, lemak, karbohidrat,

\footnotetext{
${ }^{1}$ Departemen Agronomi dan Hortikultura, Fakultas Pertanian, Institut Pertanian Bogor

${ }^{2}$ Pusat Kajian Hortikultura Tropika, Lembaga Penelitian dan Pemberdayaan Masyarakat, Institut Pertanian Bogor

*Email: untuk korespondensi. darda@ipb.ac.id
} 
vitamin, dan mineral buah melon banyak dimanfaatkan untuk terapi kesehatan. Menurut Samadi (2007) melon mempunyai khasiat bagi tubuh yaitu untuk mencegah penyakit sariawan, luka pada tepi mulut, penyakit mata, radang saraf, sebagai anti kanker, menurunkan resiko stroke dan kanker. Kesadaran masyarakat mengenai pola hidup sehat menyebabkan kebutuhan dan permintaan buah melon terus meningkat (Sukmaningtyas dan Hartoyo, 2013).

Menurut data dari Pusat Kajian Hortikultura Tropika (PKHT) (2014), konsumsi buah melon pada tahun 2008 adalah $0.16 \mathrm{~kg} /$ kapita/tahun. Terjadi peningkatan pada tahun 2011, konsumsi melon masyarakat Indonesia mencapai $0.72 \mathrm{~kg} / \mathrm{kapita} / \mathrm{tahun}$. Peningkatan konsumsi ini harus diimbangi dengan ketersediaan buah melon yang berarti perlu dilakukannya peningkatan produksi. Produksi buah melon mengalami penurunan pada kurun waktu 2011-2012 yaitu 103840 ton menjadi 70583 ton (Ditjenhorti, 2014). Penurunan produksi melon ini menyebabkan perlu dilakukannya peningkatan penyediaan benih melon agar produktivitas melon dapat optimal.

Ketersediaan benih melon hingga saat ini menjadi salah satu kendala dalam memproduksi melon. Hampir semua benih yang ditanam oleh petani melon merupakan benih impor. Harga benih yang tinggi menyebabkan usaha tani melon tidak efisien secara ekonomi (Yekti, 2005). Data impor benih melon pada tahun 2012 adalah mencapai US\$ 69240 atau setara dengan 800 juta rupiah (Ditjenhorti, 2014). Hal ini menjadi penyebab perlunya tindakan untuk memproduksi benih melon dalam negeri. Jika ini terjadi maka petani dapat dengan mudah mendapatkan benih melon dengan harga yang lebih murah.

PKHT melakukan serangkaian kegiatan pemuliaan tanaman melon untuk menghasilkan melon yang unggul. Hingga saat ini PKHT telah memperoleh beberapa genotipe melon yang siap dievaluasi yang kemudian direncanakan untuk didaftarkan di Pusat Perlindungan Varietas Tanaman atau dilepas sebagai varietas baru. Program evaluasi dalam penelitian ini mencakup sejumlah karakter penting pada melon, meliputi penampilan tanaman, kualitas buah (aroma, rasa), dan ketahanan terhadap penyakit utama.

\section{BAHAN DAN METODE}

Penelitian dilaksanakan di Kebun Percobaan Pusat Kajian Hortikultura Tropika Tajur II Bogor pada bulan September sampai Desember 2013. Bahan yang digunakan pada penelitian ini adalah empat genotipe melon yaitu IPB Meta 3, IPB Meta 4, IPB Meta 6, IPB Meta $8 \mathrm{H}$, dan dua varietas pembanding yaitu Action 434 dan Sky Sweet. Sarana produksi yang digunakan adalah pupuk kandang, pupuk majemuk NPK (16-16-16), pupuk tunggal (Urea, $\mathrm{KCl}$, dan SP36), $\mathrm{KNO}_{3}$, beberapa jenis pestisida, ZPT (Zat Pengatur Tumbuh) berupa giberelin (GA-3), bak semai, media semai, ajir, tali, serta mulsa Plastik Hitam Perak (PHP) dengan lebar $100-125 \mathrm{~cm}$.

Penelitian dilakukan dengan menggunakan Rancangan Kelompok Lengkap Teracak (RKLT) faktor tunggal dengan empat ulangan. Pelaksanaan percobaan diawali dengan merendam benih dalam air hangat (suhu $\pm 40{ }^{\circ} \mathrm{C}$ ) mengandung giberelin (GA-3) dengan konsentrasi $0.2 \mathrm{mg} \mathrm{l}^{-1}$ selama 4 jam. Kemudian benih ditiriskan dan diletakkan di atas kertas koran selama 1 hari 2 malam (36 jam). Selanjutnya benih disemaikan ke dalam bak semai yang berisi campuran tanah dan pupuk kandang dengan perbandingan 1:1.

Pembibitan ini dilakukan selama 14 hari. Persiapan lahan dilakukan sesuai rancangan percobaan, yaitu menggunakan 8 bedeng dengan masing-masing bedeng memiliki panjang $23 \mathrm{~m}$ dan lebar $1 \mathrm{~m}$. Tanah diolah sampai kedalaman 20-30 cm, diberi pupuk kandang dengan dosis $2 \mathrm{~kg}$ tanaman $^{-1}$, SP-36 $30 \mathrm{~g}^{\text {tanaman }}{ }^{-1}$, Urea 20 $\mathrm{g}$ tanaman $^{-1}, \mathrm{KCl} 20 \mathrm{~g}$ tanaman $^{-1}$. Pengolahan tanah ini dilakukan pada 12 hari sebelum tanam, sedangkan pemasangan mulsa dilakukan pada 10 hari sebelum tanam. Selanjutnya, dibuat lubang tanam dengan jarak $50 \mathrm{~cm} \times 50 \mathrm{~cm}$.

Pemindahan bibit dilakukan pada 14 hari setelah semai. Penanaman dilakukan pada pagi hari. Kegiatan selanjutnya adalah pemeliharaan yang meliputi: penyulaman, pengajiran, pemupukan susulan, pengikatan, penyemprotan pestisida, pemangkasan, dan pemeliharaan buah. Seluruh kegiatan pemeliharaan disesuaikan dengan Standard Operational Procedure (SOP) penanaman melon yang berlaku.

Pengamatan terhadap karakter kuantitatif genotipe-genotipe melon yang dievaluasi meliputi diameter batang, panjang daun, lebar daun, umur berbunga hermafrodit, serangan penyakit 
embun bulu, serangan penyakit embun tepung, umur panen, bobot buah, ketebalan daging buah, daya simpan, kandungan air buah, kadar gula, kandungan vitamin $\mathrm{C}$, dan bobot 100 butir benih. Adapun pengamatan kualitatif terdiri atas bentuk penampang batang, warna batang, bentuk daun, warna daun, perkembangan cuping daun, panjang cuping terminal, bentuk buah, tipe kulit buah, warna daging buah, aroma buah, posisi dari lebar buah maksimum, bentuk irisan buah membujur, tingkat kekeriputan permukaan buah, lebar maksimum irisan melintang lapisan luar buah, bentuk biji, dan warna biji.

Data kuantitatif yang diperoleh dianalisis menggunakan uji $\mathrm{F}$, dan apabila terdapat pengaruh nyata genotipe, maka analisis dilanjutkan dengan uji perbedaan nilai tengah terhadap varietas pembanding dengan metode Beda Nyata Jujur (BNJ) pada taraf 5\%. Data kualitatif dihitung modusnya untuk tiap genotipe dan tiap karakter, kemudian ditampilkan dalam bentuk deskripsi. Sejumlah karakter yang diamati berpedoman pada deskriptor IPGRI (2003). Koefisien korelasi fenotipik Pearson (r) dihitung untuk mengetahui keeratan hubungan antar peubah. Analisis gerombol genotipe melon dilakukan untuk mengetahui kemiripan antar genotipe melon yang diuji menggunakan metode Gower. Sidik ragam, uji lanjut, dan analisis korelasi dilakukan menggunakan perangkat lunak SAS, sedangkan analisis gerombol menggunakan $\mathrm{R}$.

\section{HASIL DAN PEMBAHASAN}

Selama masa persemaian, benih tumbuh dengan baik dengan daya berkecambah $97 \%$ hingga $100 \%$. Pertumbuhan yang baik ini didukung oleh suplai air yang baik. Hal ini dilakukan untuk mengurangi kekurangan air yang dapat menyebabkan ukuran tanaman yang lebih kecil dibandingkan dengan tanaman yang tumbuh normal (Kurniasari et al., 2010). Kekurangan air pada tanaman menyebabkan penurunan hasil yang sangat signifikan dan berpotensi menjadi penyebab kematian pada tanaman (Salisbury dan Ross, 1992).

\section{Evaluasi terhadap Karakter Kuantitatif Tanaman}

Menurut Gomez dan Gomez (1995) nilai koefisien keragaman (KK) merupakan suatu nilai yang menggambarkan keterandalan percobaan. Hasil analisis ragam pada Tabel 1 menunjukkan bahwa terdapat perbedaan yang sangat nyata antar genotipe pada karakter diameter batang, panjang daun, lebar daun, umur berbunga hermafrodit, bobot buah, ketebalan daging buah, daya simpan, kadar gula dan bobot 100 butir benih. Di sisi lain, pengaruh genotipe tidak nyata pada karakter serangan penyakit embun bulu dan embun tepung, umur panen, kandungan air buah dan kandungan vitamin $\mathrm{C}$.

Perbedaan antar ulangan terlihat nyata pada karakter lebar daun, serangan penyakit embun bulu, umur panen, daya simpan, kandungan air buah, kadar gula, dan bobot 100 butir benih, namun pengaruh ulangan tidak nyata pada karakter diameter batang, panjang daun, umur berbunga, serangan penyakit embun tepung, bobot buah, ketebalan daging buah, dan kandungan vitamin C. Adanya pengaruh ulangan yang nyata di sejumlah peubah menunjukkan bahwa penggunaan RKLT dalam penelitian ini dinilai tepat.

Hasil uji perbandingan BNJ (Tabel 2) menunjukkan bahwa diameter batang pada genotipe IPB Meta 4 nyata lebih besar dibandingkan varietas Action 434 dan Sky Sweet. IPB Meta 3 dan Meta 4 memiliki ukuran daun yang nyata lebih besar dibandingkan Sky Sweet. Dengan daun yang besar diharapkan fotosintesis berjalan dengan baik, dimana fotosintesis diketahui merupakan proses penting untuk mempertahankan pertumbuhan dan perkembangan tanaman.

Secara umum umur berbunga yang diharapkan adalah umur berbunga yang cepat. Genotipe IPB Meta 4 dan IPB Meta 8H memiliki umur berbunga hermafrodit yang nyata lebih lambat dibandingkan varietas pembanding, Action 434 dan Sky Sweet. Umur berbunga secara umum dipengaruhi oleh faktor intern yakni genetik tanaman dan faktor lingkungan (Badrudin et al., 2009). Berdasarkan nilai koefisien keragaman $(0.9 \%)$, pengaruh faktor lingkungan terhadap umur berbunga relatif kecil dibandingkan faktor genetik.

Hasil pengamatan pada serangan penyakit embun bulu dan embun tepung menunjukkan bahwa perbedaan antar genotipe yang tidak signifikan. Tingginya koefisien keragaman untuk peubah serangan embun tepung menandakan adanya perbedaan respon yang besar di dalam genotipe yang sama, sekalipun pengaruh ulangan sudah diperhitungkan. 
Tabel 1. Rekapitulasi sidik ragam peubah kuantitatif genotipe melon

\begin{tabular}{|c|c|c|c|}
\hline Peubah $^{\mathrm{a}}$ & KT Ulangan & KT Genotipe & $\mathrm{KK}(\%)$ \\
\hline Diameter batang & $0.00^{\mathrm{tn}}$ & $0.01^{* *}$ & 3.3 \\
\hline Panjang daun & $2.62^{\mathrm{tn}}$ & $8.79^{* *}$ & 4.3 \\
\hline Lebar daun & $5.61^{* *}$ & $7.54^{* *}$ & 3.5 \\
\hline Umur berbunga hermafrodit & $2.89^{\mathrm{tn}}$ & $22.67^{* *}$ & 3.8 \\
\hline Serangan penyakit embun bulu ${ }^{+}$ & $6.30^{* *}$ & $1.27^{\mathrm{tn}}$ & 12.9 \\
\hline Serangan penyakit embun tepung ${ }^{+}$ & $19.24^{\mathrm{tn}}$ & $6.83^{\mathrm{tn}}$ & 38.2 \\
\hline Umur panen & $3.04^{* *}$ & $1.14^{\mathrm{tn}}$ & 0.9 \\
\hline Bobot buah & $27158.33^{\text {tn }}$ & $477098.25^{* *}$ & 10.2 \\
\hline Ketebalan daging buah & $0.02^{\mathrm{tn}}$ & $0.66^{* *}$ & 6.9 \\
\hline Daya simpan & $6.94^{*}$ & $20.17^{* *}$ & 11.1 \\
\hline Kandungan air buah & $1.43^{*}$ & $0.55^{\mathrm{tn}}$ & 0.6 \\
\hline Kadar gula & $1.35^{* *}$ & $1.24^{* *}$ & 6.1 \\
\hline Kandungan Vitamin $\mathrm{C}^{+}$ & $0.03^{\mathrm{tn}}$ & $0.12^{\mathrm{tn}}$ & 16.1 \\
\hline Bobot 100 butir benih & $0.27^{*}$ & $0.34^{* *}$ & 10.2 \\
\hline
\end{tabular}

Keterangan: ${ }^{a} \mathrm{KT}=$ Kuadrat tengah, $\mathrm{KK}=$ Koefisien keragaman; *, ** = Berpengaruh nyata pada taraf 5\% dan $1 \%$. tn $=$ Tidak berpengaruh nyata; ${ }^{+}=$Data ditransformasi ke $\sqrt{x+0.5}$ sebelum dianalisis .

Tabel 2. Nilai tengah peubah diameter batang, panjang daun, lebar daun, umur berbunga hermafrodit, serta serangan penyakit embun bulu dan embun tepung

\begin{tabular}{|c|c|c|c|c|c|c|}
\hline \multirow[t]{2}{*}{ Genotipe $^{\mathrm{a}}$} & $\begin{array}{c}\text { Diameter } \\
\text { Batang }\end{array}$ & $\begin{array}{c}\text { Panjang } \\
\text { Daun }\end{array}$ & $\begin{array}{l}\text { Lebar } \\
\text { Daun }\end{array}$ & $\begin{array}{c}\text { Umur Berbunga } \\
\text { Hermafrodit }\end{array}$ & $\begin{array}{c}\text { Serangan } \\
\text { Embun Bulu }\end{array}$ & $\begin{array}{c}\text { Serangan } \\
\text { Embun Tepung }\end{array}$ \\
\hline & \multicolumn{3}{|c|}{----------------cm------------- } & ---HST--- & \multicolumn{2}{|c|}{-----------\%"---------- } \\
\hline IPB Meta 3 & 1.00 & $22.5^{b}$ & $23.2^{b}$ & 29 & 57.5 & 82.5 \\
\hline IPB Meta 4 & $1.09^{\mathrm{ab}}$ & 21.7 & $23.5^{\mathrm{b}}$ & $34^{\mathrm{ab}}$ & 75.0 & 52.5 \\
\hline IPB Meta 6 & 0.94 & $18.2^{\mathrm{a}}$ & $19.8^{\mathrm{a}}$ & 28 & 77.5 & 62.5 \\
\hline IPB Meta $8 \mathrm{H}$ & $1.07^{\mathrm{a}}$ & 21.5 & 22.4 & $32^{\mathrm{ab}}$ & 70.0 & 70.0 \\
\hline Action 434 & 0.99 & 20.8 & 21.8 & 28 & 57.5 & 82.5 \\
\hline Sky Sweet & 1.02 & 20.3 & 21.2 & 28 & 75.0 & 40.0 \\
\hline
\end{tabular}

Tabel 3. Nilai tengah peubah umur panen, bobot buah, ketebalan daging buah, daya simpan, dan bobot 100 butir benih

\begin{tabular}{lccccc}
\hline \multirow{2}{*}{ Genotipe $^{\mathrm{a}}$} & Umur Panen & Bobot Buah & $\begin{array}{c}\text { Ketebalan } \\
\text { Daging buah }\end{array}$ & $\begin{array}{c}\text { Daya } \\
\text { Simpan }\end{array}$ & $\begin{array}{c}\text { Bobot 100 } \\
\text { Butir benih }\end{array}$ \\
\cline { 2 - 6 } & ---HST--- & ---- gram--- & ---- cm--- & ---hari-- & ---gram--- \\
\hline IPB Meta 3 & 64 & $837.1^{\mathrm{ab}}$ & $2.2^{\mathrm{ab}}$ & $8^{\mathrm{ab}}$ & 2.67 \\
IPB Meta 4 & 64 & $653.3^{\mathrm{ab}}$ & $2.3^{\mathrm{ab}}$ & $10^{\mathrm{ab}}$ & $2.13^{\mathrm{b}}$ \\
IPB Meta 6 & 64 & $926.5^{\mathrm{ab}}$ & $2.2^{\mathrm{ab}}$ & 11 & 2.94 \\
IPB Meta 8H & 65 & $756.5^{\mathrm{ab}}$ & $2.4^{\mathrm{ab}}$ & 11 & 2.37 \\
Action 434 & 65 & 1375.8 & 2.9 & 14 & 2.53 \\
Sky Sweet & 65 & 1494.1 & 3.2 & 14 & 2.78 \\
\hline
\end{tabular}

Keterangan: ${ }^{\mathrm{a}} \mathrm{a}=$ berbeda nyata terhadap varietas Action $434 ; \mathrm{b}=$ berbeda nyata terhadap varietas Sky Sweet berdasarkan uji BNJ pada taraf uji 5\%.

Umur panen yang diharapkan adalah umur panen yang lebih cepat dibandingkan kedua varietas pembanding. Umur panen pada keempat genotipe yang dievaluasi tidak menunjukkan perbedaan yang nyata terhadap Action 434 dan Sky Sweet (Tabel 3). Keempat genotipe yang diuji memiliki ketebalan daging buah yang nyata lebih tipis dibandingkan Action 434 dan Sky Sweet. Menurut Anggraito (2004) ketebalan daging buah melon sangat menentukan produksi tanaman. 
Tabel 4. Nilai tengah pada peubah kandungan air buah, kadar gula, kandungan vitamin C

\begin{tabular}{cccc}
\hline Genotipe $^{\mathrm{a}}$ & $\begin{array}{c}\text { Kandungan } \\
\text { Air Buah } \\
----\%----\end{array}$ & $\begin{array}{c}\text { Kadar } \\
\text { Gula } \\
\text { - }^{\mathrm{o}} \text { Brix- }\end{array}$ & $\begin{array}{c}\text { Kandungan } \\
\text { Vitamin C } \\
-- \text {-mg--- }\end{array}$ \\
\hline IPB Meta 3 & 94.5 & 5.2 & 4.4 \\
IPB Meta 4 & 95.3 & $4.2^{\mathrm{ab}}$ & 4.4 \\
IPB Meta 6 & 96.2 & 5.3 & 6.8 \\
IPB Meta 8H & 95.1 & $5.1^{\mathrm{a}}$ & 5.1 \\
Action 434 & 94.9 & 5.8 & 5.2 \\
Sky Sweet & 94.7 & 5.6 & 5.3
\end{tabular}

Keterangan: ${ }^{\mathrm{a}} \mathrm{a}=$ berbeda nyata terhadap varietas Action 434; $\mathrm{b}=$ berbeda nyata terhadap varietas Sky Sweet berdasarkan uji BNJ pada taraf uji $5 \%$.

Hasil pada pengamatan karakter bobot buah menunjukkan bahwa keempat genotipe yang diuji nyata lebih kecil dibandingkan Sky Sweet dan Action 434. Nilai bobot buah yang lebih kecil ini tidak selalu berarti sebuah kekurangan, meskipun pada umumnya petani maupun konsumen mengharapkan ukuran dan bobot buah melon yang besar (Wagiono dan Hamrah, 2007). Varietas melon berukuran kecil sudah dipasarkan di negara lain seperti di Taiwan yang ditujukan untuk konsumsi pribadi dan dapat dihabiskan dalam satu atau dua kesempatan (Bezirganoglu et al., 2013). Daya hasil per hektar dari melon tipe kecil diharapkan dapat diimbangi dengan produksi dua sampai tiga buah per tanaman, dimana penelitian lebih lanjut diperlukan untuk hal ini.

Daya simpan pada genotipe IPB Meta 3 dan IPB Meta 4 memiliki nilai yang lebih rendah dibandingkan kedua varietas pembanding Namun demikian, daya simpan buah (8-10 hari) tidak terlalu jauh berbeda dengan varietas pembanding (14 hari), dan diperkirakan akan dapat memenuhi aspek praktis dalam komersialisasi. Bobot 100 butir benih benih genotipe IPB Meta 4 nyata lebih rendah dibandingkan Sky Sweet, menandakan bahwa ukuran benih genotipe ini relatif lebih kecil. Ketiga genotipe IPB lainnya tidak berbeda bobot 100 butir benih benihnya dengan kedua varietas pembanding.
Kandungan air buah dan kandungan vitamin C (Tabel 4) pada melon yang diuji tidak berbeda nyata dengan varietas pembanding. Kandungan gula pada genotipe IPB Meta 4 $\left(4.2^{\circ}\right.$ Brix) nyata lebih rendah dibandingkan Action 434 (5.8 ${ }^{\circ}$ Brix) dan Sky Sweet (5.6 ${ }^{\circ}$ Brix), namun perbedaan rasa buah untuk kisaran kandungan gula tersebut dinilai tidak terlalu berarti. Kandungan gula yang umumnya relatif rendah diduga sebagai akibat dari teknik aplikasi pupuk $\mathrm{KNO}_{3}$ yang kurang optimal. Pengaplikasian di lapangan pemberian pupuk $\mathrm{KNO}_{3}$ dilakukan dengan disemprotkan pada seluruh bagian tanaman, namun diperkirakan metode yang lebih baik adalah aplikasi di lubang tanam.

\section{Evaluasi terhadap Karakter Kualitatif Tanaman}

Tabel 5 menunjukkan bahwa genotipe IPB Meta 3, Meta 4, dan Meta 8H memiliki warna daun hijau, sedangkan genotipe IPB Meta 6, Action 434 dan Sky Sweet berwarna hijau tua. IPB Meta 3 dan Meta 6 memiliki perkembangan cuping daun lemah, sedangkan IPB Meta 4, Meta 8H, Action 434 dan Sky Sweet memiliki perkembangan cuping daun sedang. Cuping terminal yang relatif panjang terdapat pada genotipe IPB Meta 4, Meta 8, dan varietas Action 434, sedangkan cuping terminal yang berukuran relatif lebih pendek terdapat pada genotipe IPB Meta 3, Meta 6, dan varietas Sky Sweet.

Tabel 5. Rekapitulasi hasil pengamatan peubah kualitatif daun

\begin{tabular}{|c|c|c|c|}
\hline Genotipe & $\begin{array}{l}\text { Warna } \\
\text { Daun }\end{array}$ & $\begin{array}{c}\text { Perkem- } \\
\text { bangan } \\
\text { Cuping } \\
\text { Daun }\end{array}$ & $\begin{array}{l}\text { Panjang } \\
\text { Cuping } \\
\text { Terminal }\end{array}$ \\
\hline IPB Meta 3 & Hijau & Lemah & Sedang \\
\hline IPB Meta 4 & Hijau & Sedang & Panjang \\
\hline IPB Meta 6 & Hijau tua & Lemah & Sedang \\
\hline IPB Meta $8 \mathrm{H}$ & Hijau & Sedang & Panjang \\
\hline Action 434 & Hijau tua & Sedang & Panjang \\
\hline Sky Sweet & Hijau tua & Sedang & Sedang \\
\hline
\end{tabular}


Tabel 6. Rekapitulasi hasil pengamatan peubah kualitatif buah

\begin{tabular}{|c|c|c|c|c|c|}
\hline Genotipe & $\begin{array}{c}\text { Bentuk } \\
\text { Buah }\end{array}$ & $\begin{array}{l}\text { Warna } \\
\text { Daging } \\
\text { Buah }\end{array}$ & $\begin{array}{c}\text { Bentuk } \\
\text { Irisan Buah } \\
\text { Membujur } \\
\end{array}$ & $\begin{array}{c}\text { Tingkat } \\
\text { Kekeriputan } \\
\text { Permukaan Buah }\end{array}$ & $\begin{array}{l}\text { Lebar Maksimum } \\
\text { Irisan Melintang } \\
\text { Lapisan Luar Buah }\end{array}$ \\
\hline IPB Meta 3 & Lonjong & Jingga & Lonjong & Kuat & Sedang \\
\hline IPB Meta 4 & Bulat & Hijau muda & Bundar & Kuat & Sedang \\
\hline IPB Meta 6 & Oblate & Jingga & Oblate & Lemah & Tebal \\
\hline IPB Meta $8 \mathrm{H}$ & Bulat & Jingga & Bundar & Kuat & Sedang \\
\hline Action 434 & Bulat & Hijau muda & Bundar & Sedang & Tebal \\
\hline Sky Sweet & Bulat & Hijau muda & Bundar & Kuat & Sedang \\
\hline
\end{tabular}

Keempat genotipe melon yang diuji memiliki keragaman dalam karakter bentuk buah, dimana IPB Meta 3 berbentuk lonjong, IPB Meta 6 oblate, dan IPB Meta 4 dan IPB Meta $8 \mathrm{H}$ bulat (Tabel 6). Genotipe IPB Meta 6 merupakan genotipe yang memiliki bentuk buah yang cukup beragam mulai dari oblat, bulat hingga lonjong, sedangkan kedua varietas pembanding memiliki bentuk buah yang bulat. Warna kulit buah melon yang diuji adalah hijau, namun pada IPB Meta 8 memiliki warna kulit buah hijau pucat. Warna daging buah yang beragam merupakan salah satu faktor ketertarikan masyarakat terhadap buah melon. Varietas melon yang banyak dipasarkan di Indonesia adalah melon dengan daging buah berwarna hijau muda, sedangkan varietas yang berwarna jingga lebih sedikit. Tabel 6 menunjukkan bahwa genotipe IPB Meta 3, IPB Meta 6 dan IPB Meta 8H memiliki daging buah berwarna jingga, menandakan adanya peluang bagi ketiga genotipe tersebut untuk dikembangkan lebih lanjut.

Keempat genotipe melon yang diuji memiliki keragaman dalam bentuk irisan buah membujur, terutama disebabkan karena bentuk buah yang berbeda-beda. Kekeriputan buah pada IPB Meta 6 sangat lemah, berbeda dengan Sky Sweet yang memiliki tingkat kekeriputan kulit yang kuat. Lebar maksimum irisan melintang lapisan luar buah pada IPB Meta 3, IPB Meta 4, IPB Meta 8H dan Sky Sweet adalah relatif sedang, sedangkan pada IPB Meta 6 dan Action 434 relatif tebal.

Semua genotipe yang diuji dan dua varietas pembanding memiliki keseragaman pada karakter bentuk penampang batang (persegi lima), warna batang (hijau muda) dan bentuk daun (pentalobate). Tipe kulit buah (berjala), aroma buah (wangi) dan posisi dari lebar maksimum yang berada di tengah buah. Bentuk biji oval dan biji berwarna krem.

\section{Korelasi antar Karakter Kuantitatif}

Berdasarkan Tabel 7, karakter panjang daun berkorelasi positif terhadap lebar daun, dimana keduanya berkontribusi terhadap luas daun.

Tabel 7. Korelasi linear antar karakter kuantitatif melon

\begin{tabular}{ccccccccccc}
\hline Peubah $^{\mathrm{a}}$ & DB & PD & LD & UB & EB & ET & UP & BB & KDB & DS \\
\hline PD & 0.663 & - & & & & & & & & \\
LD & 0.752 & $0.956^{* *}$ & - & & & & & & & \\
UB & $0.879 *$ & 0.497 & 0.683 & - & & & & & & \\
EB & 0.146 & -0.569 & -0.414 & 0.270 & - & & & & & \\
ET & -0.280 & 0.325 & 0.227 & -0.173 & $-0.843^{*}$ & - & & & & \\
UP & 0.166 & 0.024 & -0.147 & -0.214 & -0.151 & -0.054 & - & & & \\
BB & -0.406 & -0.316 & -0.474 & -0.745 & -0.155 & -0.183 & -0.639 & - & & \\
KDB & -0.006 & -0.108 & -0.237 & -0.423 & -0.040 & -0.369 & 0.786 & $0.914^{*}$ & - & \\
DS & -0.151 & -0.433 & -0.504 & -0.423 & 0.118 & -0.317 & 0.781 & $0.850^{*}$ & $0.887 *$ & - \\
SB & $-0.888^{*}$ & -0.656 & -0.798 & $-0.893^{*}$ & 0.066 & -0.025 & -0.038 & 0.489 & 0.161 & 0.190 \\
\hline
\end{tabular}

Keterangan: ${ }^{\mathrm{a}} *,{ }^{* *}=$ Berbeda nyata terhadap $\mathrm{r}=0$ masing masing pada taraf $5 \%$ dan $1 \%$; DB= Diameter batang; $\mathrm{PD}=$ Panjang daun; $\mathrm{LD}=$ Lebar daun; $\mathrm{UB}=\mathrm{Umur}$ berbunga hermafrodit; $\mathrm{EB}=$ Serangan penyakit embun bulu; $\mathrm{ET}=$ Serangan penyakit embun tepung; $\mathrm{UP}=\mathrm{Umur}$ panen; $\mathrm{BB}=\mathrm{Bobot}$ buah; $\mathrm{KDB}=$ Ketebalan daging buah; DS; Daya simpan; SB= Bobot 100 butir benih. 
Karakter tebal daging buah berkorelasi positif terhadap bobot buah, dan keduanya juga berkorelasi positif terhadap daya simpan buah. Hal ini menunjukkan bahwa genotipe yang memiliki daging buah tebal dan bobot buah besar cenderung memiliki daya simpan yang relatif lama. Karakter serangan penyakit embun bulu berkorelasi negatif dengan serangan embun tepung, mengindikasikan bahwa kedua gejala penyakit tersebut tidak muncul pada waktu yang bersamaan.

\section{Pengelompokan Genotipe}

Pengelompokan genotipe melon menunjukkan bahwa genotipe melon IPB Meta 6 berbeda pada tingkat $62 \%$ dengan kelima genotipe melon lainnya (Gambar 1), yang dicirikan oleh karakter bobot 100 butir benih, kandungan air buah, kandungan vitamin $\mathrm{C}$, dan bentuk buah.

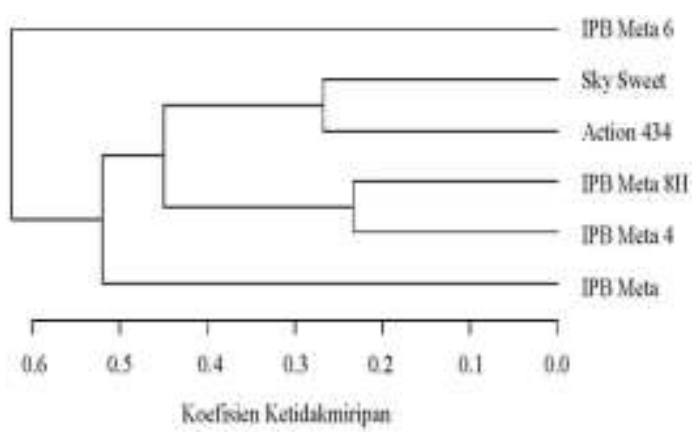

Gambar 1. Dendrogram Pengelompokan Enam Genotipe Melon dari Data Kuantitatif dan Kualitatif

Genotipe IPB Meta 6 memiliki bobot 100 butir benih yang lebih berat dibandingkan genotipe lain. Kandungan air buah pada IPB Meta 6 memiliki persentase yang paling tinggi (96.2\%) dibandingkan genotipe lain. Kandungan vitamin C pada IPB Meta 6 adalah $6.8 \mathrm{mg}$, sedangkan genotipe lainnya berkisar antara 4$5 \mathrm{mg}$. Bentuk buah IPB Meta 6 adalah oblate, sedangkan genotipe lainnya memiliki bentuk buah bulat dan lonjong. Disamping itu, IPB Meta 3 berbeda pada tingkat $52 \%$ dengan genotipe IPB Meta 4, IPB Meta 8H, Action 434 dan Sky Sweet. Perbedaan tersebut terdapat dalam karakter panjang daun, daya simpan buah, dan bentuk buah. IPB Meta 3 memiliki panjang daun $22.5 \mathrm{~cm}$, sedangkan IPB Meta 4 , IPB Meta 8H, Action 434 dan Sky Sweet memiliki panjang daun berkisar antara 20-21 cm. IPB Meta 3 tahan disimpan dalam waktu 8 hari, sedangkan keempat genotipe lainnya dapat disimpan 10-14 hari. Bentuk buah IPB Meta 3 adalah lonjong, sedangkan keempat genotipe yang lainnya adalah bulat.

\section{KESIMPULAN}

IPB Meta 4 memiliki diameter batang dan ukuran daun yang lebih besar dibandingkan Action 434 dan Sky Sweet. Genotipe IPB Meta 3, IPB Meta 6 dan IPB Meta 8H memiliki warna daging buah melon yang berwarna jingga, dimana kedua varietas pembanding berwarna hijau. Ukuran buah melon IPB yang relatif kecil dapat menambah koleksi genotipe hasil pemuliaan IPB untuk segmen pasar khusus, yang diharapkan dapat mengantisipasi perubahan preferensi konsumen di masa mendatang.

\section{DAFTAR PUSTAKA}

Anggraito, Y.U. 2004. Identifikasi berat, diameter, dan tebal daging buah melon (Cucumis melo L.) kultivar action 434 tetraploid akibat perlakuan kolkisin. J. Berk. Penel. Hayati. 10: (37-42).

Badrudin, U., B. Suryotomo, Wahidin. 2009. Uji daya hasil dan pertumbuhan beberapa genotipe melon (Cucumis melo L.) hibrida di Kabupaten Pekalongan. Skripsi. Fakultas Pertanian Universitas Pekalongan. Pekalongan.

Bezirganoglu, I., S.Y. Hwang, T.J. Fang, Shaw F.J. 2013. Transgenic lines of melon (Cucumis melo L. var. makuwa cv. 'Silver Light') expressing antifungal protein and chitinase genes exhibit enhaced resistance to fungal pathogens. PCTOC Journal of Plant Biotechnology. 112: 227-237.

[Ditjenhorti] Direktorat Jenderal Hortikultura. 2014. Nilai ekspor impor benih buah 2009-2012. http//hortikultura.pertanian. go.id/index.php?option=com_content\& view $=$ article $\&$ id $=377 \&$ Itemid $=712$. $\quad[20$ Mei 2014]. 
[Ditjenhorti] Direktorat Jenderal Hortikultura. 2014. Nilai produksi buah 2009-2012. http://hortikultura.pertanian.go.id/index. php?option $=$ com_content $\&$ view $=$ article \&id=315\&Itemid=915. [20 Mei 2014].

Gomez, K.A., A.A. Gomez. 1995. Prosedur Statistik untuk Penelitian Pertanian. Edisi Kedua. Universitas Indonesia (UI Press). Jakarta.

[IPGRI] International Plant Genetic Resources Institute. 2003. Descriptors for Melon (Cucumis melo L). International Plant Genetic Resources Institute. Rome.

Kurniasari, A.M., Adisyahputra, R. Rosman. 2010. Pengaruh kekeringan pada tanah bergaram $\mathrm{NaCl}$ terhadap pertumbuhan tanaman nilam. Skripsi. Jurusan Biologi FMIPA UI. Jakarta.

[PKHT] Pusat Kajian Hortikultura Tropika. 2014. Konsumsi buah perkapita hortikultura. http://pkht.or.id/datastatistik/konsumsi-buah-dan-sayur. [20 Mei 2014].

Prajnanta, F. 2004. Melon, Pemeliharaan Secara Intensif dan Kiat Sukses Beragribisnis. Cetakan ke-6. Penebar Swadaya. Jakarta.

Rubatzky, V., Yamaguchi. 1999. Sayuran Dunia: Prinsip, Produksi dan Gizi. H. Catur, penerjemah: N. Sofia, Terjemahan: ITB Press. Bandung.

Salisbury, F.B., C.W. Ross. 1992. Plant Physiology. 4rd Ed. Wadsworth Publishing Company. California. US.

Samadi B. 2007. Melon, Usaha Tani dan Penanganan Pascapanen. Kanisius. Yogyakarta.
Saptana, S. Masdjidan, W. Sri, K.D. Saktyany, A. Ening, D. Valeriana. 2005. Pemantapan Model Pengembangan Kawasan Agribisnis Sayuran Sumatera (KASS). Puslitbang Deptan. Bogor.

Sari, D.P., C.G. Yohanes, P. Darwin. 2013. Pengaruh konsentrasi kalsium terhadap pertumbuhan dan produksi dua varietas tanaman melon (Cucumis melo L.) pada sistem hidroponik media padat. J. Agrotropika. 18(1): 29-33.

Sudiyarto. 2011. Strategi pemasaran buah lokal Jawa Timur. J-SEP. 5(1): 65-73.

Sukmaningtyas, A., Hartoyo. 2013. Pengaruh nilai dan gaya hidup terhadap preferensi dan perilaku pembelian buah-buahan impor. Jurnal Ilmu Keluarga \& Konsumen. 6(1): 39-48.

Supriyono, J.K. Sutopo, W. Heri, M. Sih. 2011. Penyususnan prosedur operasional buku budidaya melon di Kabupaten Grobogan. J. of Rural and Development. 2(1): 1-8.

[UPOV] Union Internationale pour la Protection des Obtentions Vegelate. 2006. Cucumis melo L. International Union For the Protection of New Varieties of Plant. Geneva.

Wagiono, Y., K., Hamrah. 2007. Metode quality function deployment (QFD) untuk informasi penyempurnaan perakitan varietas melon. J. Agribisnis dan Ekonomi Pertanian. 1(2): 48-57.

Yekti, A. 2005. Efisiensi ekonomi usaha tani melon di Kecamatan Wedi, Kabupaten Klaten. J. Ilmu-ilmu Pertanian. 1(1): 50-60. 